\title{
An open-source tool to assess the carbon footprint of research
}

\author{
Jérôme Mariette * $\quad$ Odile Blanchard ${ }^{\dagger} \quad$ Olivier Berné ${ }^{\ddagger}$ \\ Tamara Ben-Ari ${ }^{\S} \quad \ldots$
}

January 14, 2021

\section{Version 1 of the paper : author list to be completed}

\begin{abstract}
Research institutions are bound to contribute to greenhouse gas emission (GHG) reduction efforts for several reasons. First, part of the scientific community's research deals with climate change issues. Second, scientists contribute to students' education : they must be consistent and role models. Third the literature on the carbon footprint of researchers points to the high level of some individual footprints. In a quest for consistency and role models, scientists, teams of scientists or universities have started to quantify their carbon footprints and debate on reduction options. Indeed, measuring the carbon footprint of research activities requires tools designed to tackle its specific features. In this paper, we present an open-source web application, GES 1point5, developed by an interdisciplinary team of scientists from several research labs in France. GES 1point5 is specifically designed to estimate the carbon footprint of research activities in France. It operates at the scale of research labs, i.e., laboratoires, which are the social structures around which research is organized in France and the smallest decision making entities in the French research system. The application allows French
\end{abstract}

*Université de Toulouse, INRAE, UR MIAT, F-31320, Castanet-Tolosan, France

†Université Grenoble Alpes, CNRS, INRAE, Grenoble INP, GAEL, 38000 Grenoble, France

${ }_{\ddagger}^{\ddagger}$ Institut de Recherche en Astrophysique et Planetologie, Université de Toulouse, CNRS, CNES, UPS, Toulouse, France, 9 Av. du colonel Roche, 31028 Toulouse Cedex 04, France

§UMR 211, INRAE, AgroParisTech, Université Paris-Saclay, F-78850 Thiverval-Grignon, France; CIRED, UMR 8568, F-94736 Nogent-sur-Marne, France 
research labs to compute their own carbon footprint along a standardized, open protocol. The data collected in a rapidly growing network of labs will be used as part of the Labos 1point5 project to estimate France's research carbon footprint. At the time of submitting this manuscript, 89 research labs had engaged with GES 1point5 to estimate their greenhouse gas emissions. We expect that an international adoption of GES 1point5 (adapted to fit domestic specifics) could contribute to establishing a global understanding of the drivers of the research carbon footprint worldwide and the levers to decrease it.

Availability and implementation: GES 1point5 is available online for French research labs at http://labos1point5.org/ges-1point5 and source code can be downloaded from the GitLab platform at https://framagit.org/labos1point5/11p5-vuejs.

Keywords: carbon footprint, research sector, WEB application 


\section{Introduction}

When signing the Paris Agreement, France committed to drastically reducing its domestic greenhouse gas (GHG) emissions within the next decades. All sectors are expected to contribute to this mitigation effort, including the public sector. Although it is expected that the research sector's direct contribution to domestic GHG emissions is small, research institutions are bound to contribute to these reduction efforts for several reasons. First, part of the scientific community's research deals with climate change issues; their results point to the need to mitigate and adapt to climate change. The whole scientific community cannot ignore those results. Second, scientists contribute to students' education and often stand at the forefront of the discussions on climate change and its impacts on ecosystems and societies : they must be consistent and be role models. Third the literature on the research sector's GHG emissions points a high footprints of some scientists Nature Astronomy, 2020, Spinellis and Louridas, 2013, Fox et al., 2009, Grémillet, 2008].

At the international level, only a small number of studies report on estimates of the carbon footprint of the research sector. These studies either focus on one single entity such as a research lab or a university Güereca et al., 2013, Wynes et al., 2019], on a specific event such as a conference Spinellis and Louridas, 2013, Desiere, 2016, Stroud and Feeley, 2015, Klöwer et al., 2020], on a single source of GHG emissions such as air travel Ciers et al., 2019], or on a specific research project [Achten et al., 2013, Barret, 2020]. When more comprehensive, these estimates relate only to one single year Güereca et al., 2013. Furthermore, all of these studies rely on the development of ad-hoc methodologies relying on a specific set of emission factors (i.e., the parameters used to convert activity levels into GHG emissions). This point prevents from any comparison between carbon footprints and highlights the need for a dedicated and standardized application.

Several tools are actually freely available. Some are designed to estimate individual or 
households' GHG emissions and may be bounded to lucrative carbon offset schemes The GHG Protoco $]^{6}$ offers a set of worksheets dedicated to industries, businesses, countries or cities. The University of New Hampshire has developed SIMAP ${ }^{\circledR 7}$, a standardized software to address the specific needs of North American education institutions, colleges, and universities. In France, Bilan Carbone ${ }^{\circledR 8}$ is a generic tool developed as a set of worksheets and requires its users to pay for a licence and a training program. None of these tools are specifically designed to estimate the carbon footprints of research activities.

In this paper, we present a free and open source standardized web application, GES 1point5. It has been developed by an interdisciplinary team of engineers and researchers who work in various research labs in France and interact in the non governmental organization Labos 1point $5^{9}$. The tool allows any research lab to (i) estimate the emissions relating to the energy consumption and refrigerant gases of its buildings, and to its members' travels (ii) easily highlight, via a graphic interface, the main GHG emissions drivers of a research lab, and (iii) design emission reduction actions and evaluate their impact over time. Because they rely on a standardized protocol, completed GES 1point5-based GHG inventories can be compared. This enables to make progress in our understanding of the drivers of the research footprint (e.g., disciplinary or geographic). At the national scale, the data collected will allow to estimate the carbon footprint of the French public research and thus support the exploration of evidence-based emission reduction strategies.

The paper is organised as follows: we first describe a few specifics of the French research system and the goals of GES 1point5; we then describe GES 1point5 methodology and its implementation; the fifth section provides an illustration of GES1 point5 outputs, namely

\footnotetext{
1 https://co2.myclimate.org/en/

2 https://www.carbonfootprint.com/

3 https://offset.climateneutralnow.org/footprintcalc

${ }^{4}$ https://nosgestesclimat.fr/simulateur/bilan

5 https://www.goodplanet.org/fr/calculateurs-carbone/particulier/

6 https://ghgprotocol.org/

7 https://www.unh.edu/sustainability/research/campus-calculator-tools

8 https://www.associationbilancarbone.fr/les-solutions/

9 https://labos1point5.org/
} 
the GHG inventory and carbon footprint of a fictitious research lab; future developments and research perspectives are addressed in the sixth section, before the conclusion.

\section{Context and goals}

The French research system encompasses several types of institutions 10 , national research institutes (such as CNRS, INRAe, CEA, IRD, ...), semi-private research institutions (such as CIRAD, Ifremer, etc.) and universities. These institutions take part in social structures called laboratoires (referred to as "research labs" in the following sections). Their financial contributions to the operation of research labs may be multiple, e.g. they may pay the salaries or stipends of its members, provide fixed assets such as buildings or infrastructures, pay for resources such as supplies, electricity, etc. A typical laboratoire benefits from the involvement of several institutions or universities. These research labs comprise between tens and at most a few hundred members, and occupy one or several buildings. A laboratoire usually focuses on a specific scientific field. France counts over 1000 public research labs overall.

In this context, the implementation of GES 1point5 was initiated to provide the French scientific community with a free and open source tool able to estimate the carbon footprint of a research lab using a standardized methodology. GES 1point5 operates at the scale of research labs for several reasons. GES 1point5 is part of Labos 1pointst a large interdisciplinary project in France that aims at fueling a bottom-up momentum by mobilizing members of the research community as opposed to decision-makers in the academic bureaucracy. Research labs are the smallest human scale entities in the research system. They rely on independent and collective decision-making processes: experimental designs, as well as access to research facilities are decided and managed at the research lab scale. Consequently, a number of decisions relevant to the reduction of the carbon footprint can be made at the

\footnotetext{
${ }^{10}$ https://www.sciencemag.org/careers/2006/04/finding-your-way-around-french-research-system

11 labos1point5.org
} 
scale of research labs.

Sharing the same methodology allows to compare and aggregate results to analyse and answer research questions at the research lab scale but also at smaller and larger scales. At the research lab scale, the carbon footprint can be analysed to understand (i), the main emission sources and the relative contribution of each activity, (ii), the relative contribution of its members according to their professional status, and (iii), the emission dynamics over time relative to the mitigation actions that may have been implemented. Indeed, GES 1point5 is meant to be a decision support tool for mitigation actions and experiments. For example, to reduce emissions from professional travels, different mitigation decisions or policies may be tested, such as an internal carbon tax or individual emission quotas.

At a smaller scale, GES 1point5 may also allow to estimate the carbon footprint of specific research projects or specific teams within the lab, that of $\mathrm{PhD}$ theses or even of conferences.

At a larger scale, another objective with GES 1point5 is to create a dataset which is a collection of the GHG footprints of a large number of research labs in France in a large array of disciplines. Combining this dataset with statistical analyses, it will be possible to perform an extrapolation to assess the overall carbon footprint of French public research, and to describe the distribution of sources of emissions across regions and disciplines.

Coupling the analyses performed at different scales with the experiences led by research labs will contribute to the construction of robust emission reduction scenarios at the global level and recommendations in terms of public research policy.

\section{$3 \quad$ GES 1point5 methodology}

GES 1point5 complies with and refers to the French legislation MEEM, 2016]. When estimating the carbon footprint of an entity, it is necessary to precisely define its scope i.e. the GHGs considered and the emission sources included, as well as to mention the emission factors chosen. The next two subsections present GES 1point5 features in these respects. 


\subsection{Scope}

As required by the French legislation, the GHGs considered in GES 1point5 are those of the Kyoto Protocol. In terms of emission sources, GES 1point5 takes into account those that are common and most often critical in research labs: buildings through energy consumption, air conditioning and refrigeration processes, daily commutes and professional travels due to the use of cars, boats or planes to attend meetings or harvest field data.

\subsection{Emission factors}

An emission factor represents the amount of GHG emissions generated by a unit of activity. The emission factors included in GES 1point5 mainly stem from the ADEME database ${ }^{12}$ that is the backbone of the French legislation. When an emission factor is missing from the ADEME database, the application refers to the most recent available studies. This is the case for example for an electric bike AVEM, 2015 or for an electric scooter Arcadis, 2019]. Furthermore, the GES 1point5 team has created customized emission factors to take into account specific research lab activities. For example, the application includes an emission factor for research campaigns at sea, based on ad-hoc estimates carried out by some laboratories.

GES 1point5 also corrects some of the ADEME database inconsistencies. For example, in its current version 13 , the ADEME database does not include manufacturing emissions in the emission factor per kilometer of a gasoline car, whereas it does for hybrid and electric cars. As manufacturing emissions are significant when considering the total emissions of a car, these emissions are included in GES 1point5 for all types of cars, using factors that were provided in a previous version of the ADEME database. More generally, GES 1point5 includes manufacturing emission factors for all vehicles when these emissions are significant, i.e., cars, buses, coaches, trains, streetcars and subways. The application includes man-

\footnotetext{
12 https://www.bilans-ges.ademe.fr/en/accueil/

${ }^{13}$ version 19.0
} 
ufacturing emissions drawn from previous versions of the ADEME database and adjusted proportionately to the weight they represented in the total emission factor of the previous versions.

All methodological choices are thoroughly detailed in the methodology section of the tool available online.

\section{Implementation}

GES 1point5 has been implemented as a set of components using VueJS4 ${ }^{14}$ and djangd frameworks. The application uses input information that can be gathered reasonably easily (provided support is granted by the administration) and converts it into a GHG footprint. For a given number of emission sources, GES 1point5 converts GHG-emitting activity levels into $\mathrm{CO}_{2}$ e (carbon dioxyde equivalent) using emission factors as described in Section 3.2 .

From its welcome page (Figure 1), the application offers its users the opportunity to estimate GHG emissions anonymously or using an authenticated account. In the latter case, GES 1point5 allows to store input and output data relating to the research lab emissions. To gather the data required, the application provides a set of forms and routines briefly described below.

\section{$4.1 \quad$ Inputs}

- General information : year of the GHG inventory ; number of lab members according to their position (e.g. research members, technicians, administrative staff, $\mathrm{PhD}$ students,post-doctoral fellows).

- Data on buildings : floor area ; consumption of electricity, heat, and refrigerant gases ; specifics related to the generation of electricity, when applicable (e.g. use of solar

\footnotetext{
${ }^{14}$ https://vuejs.org/

${ }^{15}$ https://www.djangoproject.com/
} 
panels).

- Data on transportation modes operated by the lab : type (e.g. car, truck, aircraft) ; type of fuel ; power, distances travelled, number of hours of operation when applicable. Figure 2 presents the form dedicated to add a new vehicle and entering its energy consumption.

- Commutes : a standardized survey dedicated to collect lab members' daily commutes is provided by GES 1point5, using the Framaform web application provided by framasoft, a not-for-profitorganization that makes the safe handling of personal data overarching. The survey is to be sent to all lab members. Once the survey period is over, results can be exported from Framaform and directly imported into GES 1point5.

- Professional travel : the raw data are extracted from the information systems of the various research institutions that pay for the travels of the lab members. For each trip, they comprise information on the date, the departure and destination places (cities, countries), the travel modes, the travel purpose, the status of the lab member. These data are imported as a .tsv file into GES 1point5, Table 1 defines the required format.

\subsection{Outputs}

As previously mentioned, GES 1point5 complies with the French legislation, which itself abides by the GHG Protocol standard WRI and WBCSD, 2004]. The application thus provides the regulatory table covering scope 1 (direct emissions from owned or controlled sources), scope 2 (indirect emissions from the generation of purchased electricity, heating and cooling), as well as some emission categories among all other indirect emissions of scope 3. The resulting table, presented in Figure 3 can be downloaded in csv format.

On top of displaying GHG emissions distribution within the three regulatory scopes, GES 1point5 provides a user-friendly synthetic representation of the research lab's carbon 
bioRxiv preprint doi: https://doi.org/10.1101/2021.01.14.426384; this version posted January 16,2021 . The copyright holder for this preprint (which was not certified by peer review) is the author/funder, who has granted bioRxiv a license to display the preprint in perpetuity. It is made available under aCC-BY-NC 4.0 International license.

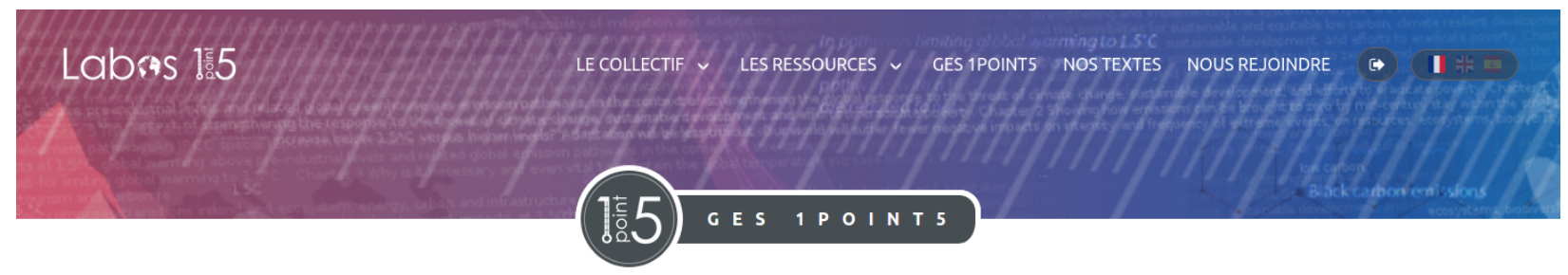

\begin{tabular}{|c|c|c|}
\hline \multicolumn{3}{|l|}{ LA DOCUMENTATION } \\
\hline E La méthodologie & $\boldsymbol{\Delta}$ & Introduction \\
\hline (3) Aide & $\boldsymbol{-}$ & $\begin{array}{l}\text { GES } 1 \text { point5, développé par Labos } 1 \text { point5, est un outil permettant de calculer l'empreinte carbone et de construire le bilan } \\
\text { gaz à effet de serre (BGES) réglementaire de votre laboratoire. }\end{array}$ \\
\hline $\begin{array}{l}\text { : L'équipe GES 1point5 } \\
\text { LES DONNÉES }\end{array}$ & - & $\begin{array}{l}\text { A travers cet outill'objectif est double: } \\
\text { - Mener des études scientifiques relatives à l'empreinte carbone de la recherche publique française (notre champ } \\
\text { d'investigation actuel est limité à la France, y compris les DOM-TOM). }\end{array}$ \\
\hline i Introduction & & $\begin{array}{l}\text { - Nourrir la réflexion sur les leviers d'actions permettant de réduire l'impact des activités de recherche sur les émissions de } \\
\text { gaz à effet de serre, tant à l'échelle nationale que locale au laboratoire. }\end{array}$ \\
\hline \multicolumn{3}{|l|}{ - Le périmètre } \\
\hline \multicolumn{3}{|l|}{ 国 Les bâtiments } \\
\hline @ Les véhicules & & $\begin{array}{l}\text { Pour trouver de l'aide et poser des questions sur l'établissement de votre BGES, vous pouvez rejoindre le forum de la communauté } \\
\text { GES } 1 \text { point5 en suivant ce lien d'invitation. }\end{array}$ \\
\hline Les missions & & Merci de bien vouloir consulter attentivement la documentation (méthodologie et aide) avant de débuter et de nous contacter. \\
\hline
\end{tabular}

LES RÉSULTATS

픈 Le bilan réglementaire

* L'approche empreinte
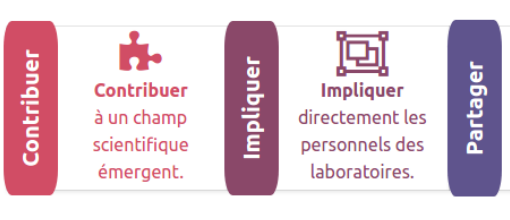

Pourquoi utiliser GES 1point5?

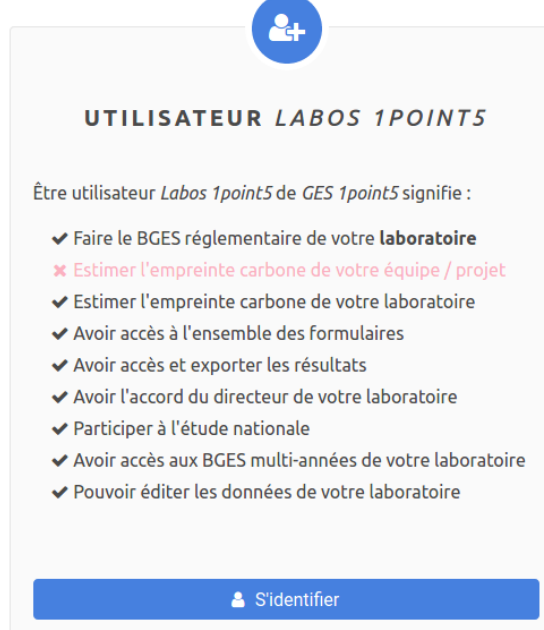

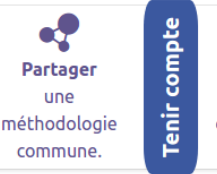

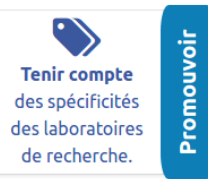

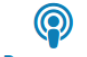

Promouvoir les outils

numériques libres.

Figure 1: The GES 1point5 welcome page offers its user the opportunity to estimate GHG emissions anonymously or using an authenticated account. The application menu, on the left, allows to navigate between documentation pages and the different emission sources forms. 
bioRxiv preprint doi: https://doi.org/10.1101/2021.01.14.426384; this version posted January 16, 2021. The copyright holder for this preprint (which was not certified by peer review) is the author/funder, who has granted bioRxiv a license to display the preprint in perpetuity. It is made available under aCC-BY-NC 4.0 International license.



Figure 2: Form to add a new vehicle to the research lab's inventory. The vehicle can be either a car, a motorbike, a bike, a scooter, an aircraft or a boat. The form requires to define the vehicle motorisation, its annual energy consumption or the number of hours / days of operation. 
Table 1: Column description of the tsv file accepted by GES 1point5 to import professional travels.

\begin{tabular}{|c|c|}
\hline Column ID & Description \\
\hline Trip number & $\begin{array}{l}\text { One line per leg of the trip ; the trip number is a } \\
\text { simple sequence number (from } 1 \text { to } n \text { ) which allows } \\
\text { to gather all the legs of the same trip. If the return } \\
\text { trip is different from the outward trip, two lines must } \\
\text { be used. }\end{array}$ \\
\hline Departure date & A date in $\mathrm{dd} / \mathrm{mm} /$ yyyy format. \\
\hline Departure city & $\begin{array}{l}\text { The departure city name. This field is used to ob- } \\
\text { tain the departure city GPS coordinates using the } \\
\text { geonames }{ }^{16} \text { database. }\end{array}$ \\
\hline Departure country & The departure country or its ISO3166 code. \\
\hline Destination city & $\begin{array}{l}\text { The destination city name. This field is used to ob- } \\
\text { tain destination city GPS coordinates using the geon- } \\
\text { ames database. }\end{array}$ \\
\hline Destination country & The destination country or its ISO3166 code. \\
\hline Travel mode & $\begin{array}{l}\text { This field can take a value among ["Avion", "Train", } \\
\text { "Voiture", "Taxi", "Bus", "Tramway", "RER", } \\
\text { "Métro", "Ferry" ]. }\end{array}$ \\
\hline Number of people in the car & $\begin{array}{l}\text { In case of a trip in a car or a taxi, number of people } \\
\text { in the vehicle }\end{array}$ \\
\hline One way / return & $\begin{array}{l}\text { If the outward and return trips are identical, enter } \\
\text { "OUI", otherwise "NON". }\end{array}$ \\
\hline Travel purpose (optional) & $\begin{array}{l}\text { This optional field allows the application to per- } \\
\text { form emissions statistics based on the travel pur- } \\
\text { pose. This field can take a value among ["Etude ter- } \\
\text { rain", "Colloque-Congrès", "Séminaire", "Enseigne- } \\
\text { ment", "Collaboration", "Visite", "Administration } \\
\text { de la recherche", "Autre" ]. }\end{array}$ \\
\hline Agent status (optional) & $\begin{array}{l}\text { This optional field allows the application to perform } \\
\text { emissions statistics based on agents' statuses. This } \\
\text { field can take a value among [ "Chercheur.e-EC", } \\
\text { "ITA", "Doc-Post doc", "Personne invitée" ]. }\end{array}$ \\
\hline
\end{tabular}

footprint. It helps the user to analyse which emission sources most impact the overall carbon footprint of the research lab, and to decide which actions to implement in order to mitigate the lab's GHG emissions. For example, in this representation, the buildings' direct and indirect emissions generated from the heating and cooling systems are aggregated, whereas they are split among the three scopes in the regulatory display. Similarly, the travel carbon 
footprint aggregates GHG emissions of vehicles, members' daily commutes and professional travels. In the regulatory table, these emissions are reported in scopes 1 and 3. Some examples of this operational representation of the carbon footprint are reported in Figures 4 and 5. All the figures provided can be downloaded in multiple formats, such as png, jpeg, svg or pdf.

\section{Illustration}

This section provides and discusses results of the 2019 greenhouse gas inventory of a fictitious research lab named Cogitamus. The lab comprises 80 members distributed as follows : 14 researchers, 24 associate professors, 17 engineers or administrative staff and $25 \mathrm{PhD}$ students or postdoctoral fellows. Cogitamus occupies one building shared with another lab and $60 \%$ of the total floor space, $3300 \mathrm{~m}^{2}$. In 2019, the building consumed $200000 \mathrm{kWh}$ PCI from the Toulouse Canceropole urban heating network, $120000 \mathrm{kWh}$ of electricity and $0.3 \mathrm{~kg}$ of the R32 cooling gas. The lab owns one diesel car which traveled $12000 \mathrm{~km}$ in 2019. For a full reproducibility of the results presented in this section, the commuting survey result: ${ }^{17}$ and the professional travel file ${ }^{18}$ used are freely available.

Figures 3, 4 and 5 illustrate the GHG emissions inventory that complies with the GHG Protocol standard, the user-friendly carbon footprint representation, graphs excerpted from GES 1point5, respectively. More specifically, figures 3 and 4 display the total emissions of the Cogitamus lab (98 $032 \pm 28525 \mathrm{~kg}$ CO2e) from two different perspectives, i.e., the regulatory GHG inventory table and the detailed carbon footprint. Figure 4 shows that these emissions are mainly driven by professional travels (64\%) followed by members' daily commutes (29\%) and electricity (4\%). Figure 5 illustrates that emissions generated by professional travels are dominated by congress attendees' travels and more specifically by researchers' travels to these congresses.

\footnotetext{
${ }^{17}$ https://cloud.le-pic.org/s/HaZWEae7ef22KMy

18 https://cloud.le-pic.org/s/msGYms2w7kqCNqJ
} 
Even if these results are fictitious, they highlight the benefits of using GES 1point5 to point to the need to focus primarily on travel emissions for an efficient mitigation action, even if reducing the buildings' emissions may be implemented in case of low-hanging fruits. Such results become even more valuable when analysing the changes in emissions over the years and evaluating the efficiency of the mitigation actions implemented.

\section{Discussion and perspectives}

GES 1point5 is a first step in a larger endeavour to facilitate and inform emission reductions from research activities in France. Estimating the carbon footprints is a crucial step to mitigate research labs' GHG emissions as it brings clearer information compared to that stemming from scopes 1, 2 and 3 of the GHG Protocol standard. The carbon footprints point to the relative weights of the main building blocks of the research labs' GHG emissions. For example, if the buildings' carbon footprint of a research lab is very low compared to its travel carbon footprint, mitigation actions should mainly focus on the travel emissions even if reducing the buildings' emissions may be implemented in case of low-hanging fruits. Similarly, within the travel carbon footprint, if the emissions from the professional travels overshadow the emissions from the staff and faculty commutes, mitigation actions should primarily focus on professional travels - even if raising awareness on the emissions from the commutes and acting to reduce them should also be addressed. GES 1point5 helps to design and monitor mitigation actions in other respects, too. At the research lab level, while storing the GHG inventories year after year, it paves the way for analyses of the lab's emissions dynamics, define and implement action plans, monitor progress and define new action plans in the long run. At the national level, statistical analyses can be carried out based on the aggregated data-set of all labs, and help to design public policies towards the mitigation of GHG emissions of the public research sector. At the time of submitting this manuscript, 89 research labs have engaged with GES 1point5 to estimate their greenhouse 
bioRxiv preprint doi: https://doi.org/10.1101/2021.01.14.426384; this version posted January 16, 2021. The copyright holder for this preprint (which was not certified by peer review) is the author/funder, who has granted bioRxiv a license to display the preprint in perpetuity. It is made available under aCC-BY-NC 4.0 International license.

\begin{tabular}{|c|c|c|c|c|c|c|c|}
\hline Poste & Description & Scope & $\mathrm{CO} 2$ & $\mathrm{CH} 4$ & N2O & Autres & $\begin{array}{c}\text { Total (kg } \\
\text { eCO2) }\end{array}$ \\
\hline$\# 1$ & Emissions directes des sources... & Scope 1 & 0 & 0 & 0 & 0 & $0 \pm 0$ \\
\hline$\# 2$ & Emissions directes des sources... & Scope 1 & 0 & 0 & 0 & 0 & $1812 \pm 1087$ \\
\hline \#3 & Emissions directes des procédé... & Scope 1 & 0 & 0 & 0 & 0 & $0 \pm 0$ \\
\hline$\# 4$ & Emissions directes fugitives & Scope 1 & 0 & 0 & 0 & 203 & $203 \pm 61$ \\
\hline$\# 5$ & Emissions issues de la biomass... & Scope 1 & 0 & 0 & 0 & 0 & $0 \pm 0$ \\
\hline Sous-total & & Scope 1 & & & & & $2015 \pm 1148$ \\
\hline \#6 & Emissions indirectes liées à l... & Scope 2 & & & & & $2844 \pm 284$ \\
\hline$\# 7$ & Emissions indirectes liées à l... & Scope 2 & & & & & $2040 \pm 612$ \\
\hline Sous-total & & Scope 2 & & & & & $4884 \pm 896$ \\
\hline$\# 8$ & Emissions liées à l'énergie no... & Scope 3 & & & & & $1735 \pm 408$ \\
\hline \#9 & Achats de produits ou services & Scope 3 & & & & & $0 \pm 0$ \\
\hline$\# 10$ & Immobilisations de biens & Scope 3 & & & & & $0 \pm 0$ \\
\hline$\# 11$ & Déchets & Scope 3 & & & & & $0 \pm 0$ \\
\hline$\# 12$ & Transport de marchandises amont & Scope 3 & & & & & $0 \pm 0$ \\
\hline$\# 13$ & Déplacements professionnels & Scope 3 & & & & & $60626 \pm 8658$ \\
\hline$\# 14$ & Actifs en leasing amont & Scope 3 & & & & & $0 \pm 0$ \\
\hline$\# 15$ & Investissements & Scope 3 & & & & & $0 \pm 0$ \\
\hline \#16 & Transport de visiteurs et de c... & Scope 3 & & & & & $0 \pm 0$ \\
\hline \#17 & Transport de marchandises aval & Scope 3 & & & & & $0 \pm 0$ \\
\hline$\# 18$ & Utilisation des produits vendus & Scope 3 & & & & & $0 \pm 0$ \\
\hline$\# 19$ & Fin de vie de produits vendus & Scope 3 & & & & & $0 \pm 0$ \\
\hline$\# 20$ & Franchise aval & Scope 3 & & & & & $0 \pm 0$ \\
\hline$\# 21$ & Leasing aval & Scope 3 & & & & & $0 \pm 0$ \\
\hline$\# 22$ & Déplacements domicile travail & Scope 3 & & & & & $\begin{array}{c}28772 \pm \\
17415\end{array}$ \\
\hline$\# 23$ & Autres émissions indirectes & Scope 3 & & & & & $0 \pm 0$ \\
\hline Sous-total & & Scope 3 & & & & & $\begin{array}{c}91133 \pm \\
26480\end{array}$ \\
\hline Total & & & & & & & $\begin{array}{c}98032 \pm \\
28525\end{array}$ \\
\hline
\end{tabular}

Figure 3: Illustration of a regulatory table obtained with the GES 1point5 tool for a fictitious research lab, presenting the emissions distributed among the three scopes of the GHG Protocol standard. The translation to English is given in Table 2 
bioRxiv preprint doi: https://doi.org/10.1101/2021.01.14.426384; this version posted January 16, 2021. The copyright holder for this preprint (which was not certified by peer review) is the author/funder, who has granted bioRxiv a license to display the preprint in perpetuity. It is made available under aCC-BY-NC 4.0 International license.

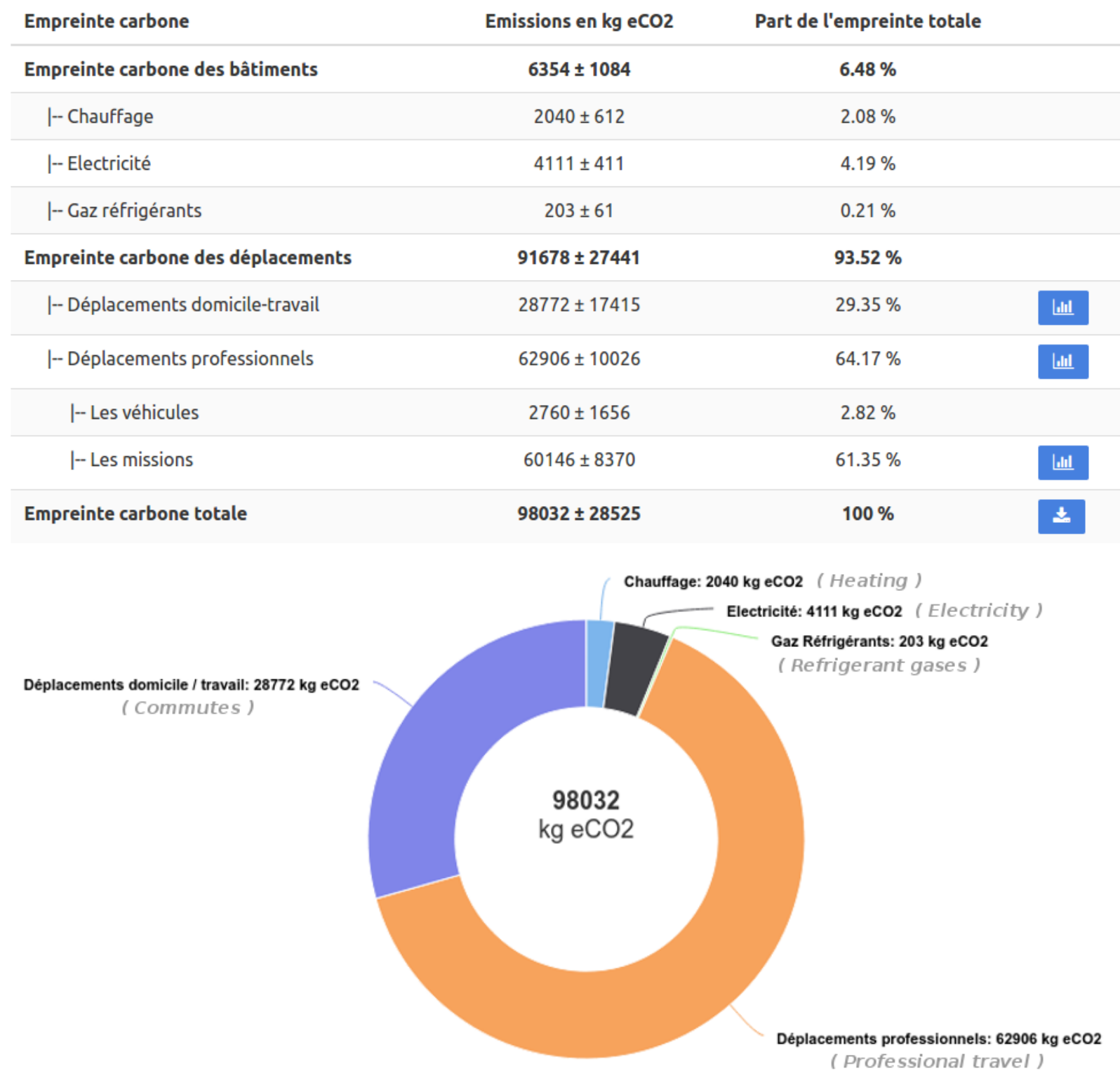

Figure 4: Illustration of the carbon footprint information provided as an output of GES 1point5 : table (upper panel) and of the pie chart (lower panel), showing the distribution of emissions in $\mathrm{kg} \mathrm{CO}$ e. Translation of the terms is provided in Table 3. 


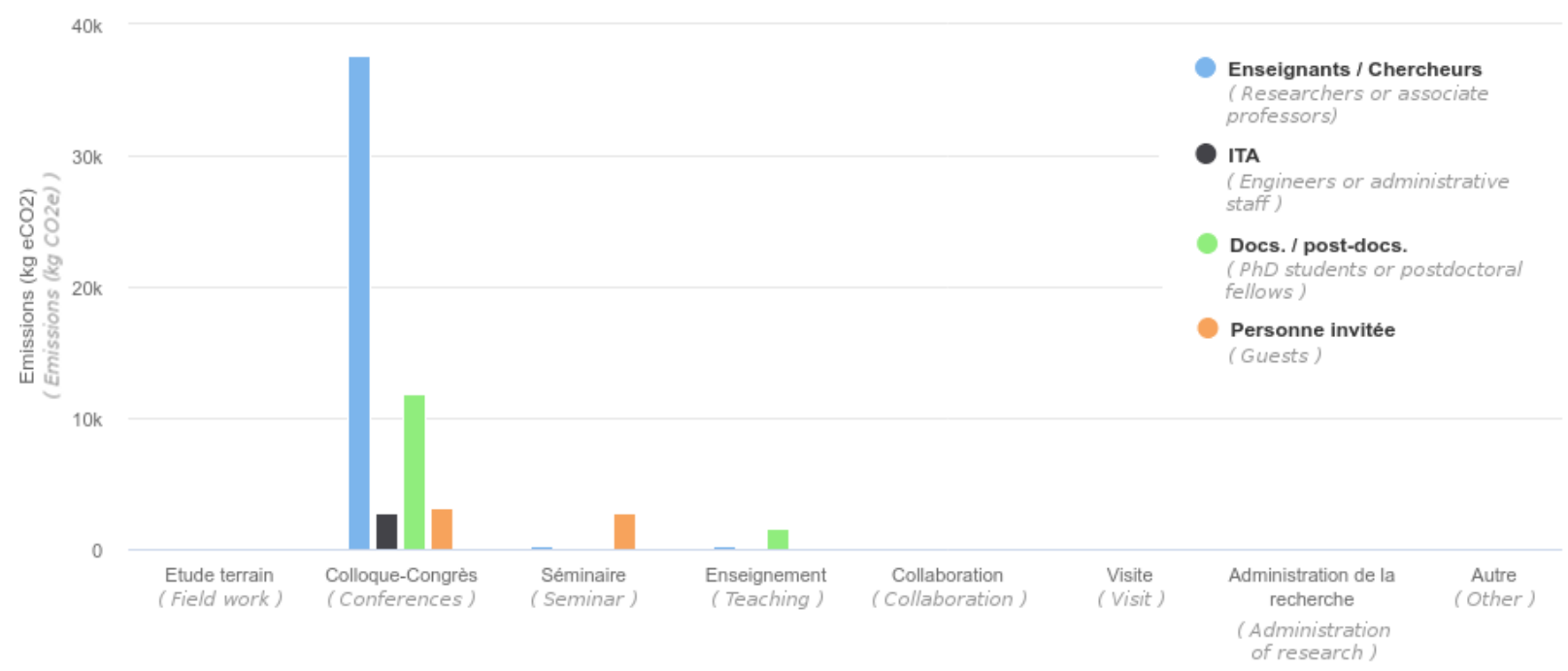

Figure 5: Illustrative distribution of the professional travel carbon footprint provided by GES 1point5 according to travel purposes and agent status.

gas emissions, only three months after the software was released. We therefore expect that a large number of labs will complete their measurement and contribute to a unique national database.

This first version of GES 1point5 presented in this paper focuses on the common emission sources that are often critical in research labs. However, other potentially important emission sources need to be soon assessed, among which internal information technology (IT) emissions, and emissions linked to purchased goods.

The estimation of the carbon footprint of IT systems internal to the research labs will be developed in GES 1point5 in future work. It will rely on the EcoDiag 19 database that provides manufacturing and transportation emission factors for multiple types of IT devices. In this case, electricity consumption emissions will not be estimated as they are already included in the emissions of the labs' buildings .

The estimation of the carbon footprint of purchased goods is complex as emission factors do not exist for all the categories of products that research labs can purchase. For example, it is frequent to use specific chemical solvents in biology labs, with only very little information

\footnotetext{
19 https://ecoinfo.cnrs.fr/ecodiag/
} 
on the manufacturing and supply chains. Various methodologies are currently under study and Labos 1point5 will thrive to consider the right trade-off between comprehensiveness and representativeness.

GES 1point5 will later on be complemented by the estimation of the GHG emissions from the use of observational and experimental infrastructures (e.g. particle accelerator, telescope).

\section{Conclusion}

The research sector must reduce the carbon footprint of its activities along with all other sectors, in order for France to reach the goal of the Paris Agreement and, more indirectly, to sustain the bond between science and society. A first step naturally pertains to estimating current emissions level. In this context, a standardized tool is essential as it paves the way for comparisons of carbon footprints, statistical analyses, fruitful dialogues, coordinated mitigation strategies and reporting of mitigation actions results in a consistent way.

As an open-source software, GES 1point5 is freely accessible to any research lab in the world. Foreign research labs may have to adjust emission factors to their country when using the application, thus enabling comparisons between research labs worldwide. GES 1point5 opens up a very broad range of international research perspectives and initiates a strategy to discuss on the best ways to reduce research emissions worldwide.

\section{References}

Nature Astronomy. The climate issue. Nature Astronomy, 4:811, 2020. doi: 10.1038/ s41550-020-01216-9.

Diomidis Spinellis and Panos Louridas. The carbon footprint of conference papers. PloS one, 8(6):e66508, 2013.

Helen E Fox, Peter Kareiva, Brian Silliman, Jessica Hitt, David A Lytle, Benjamin S Halpern, Christine V Hawkes, Joshua Lawler, Maile Neel, Julian D Olden, Martin A Schlaepfer, Katherine Smith, and Heather Tallis. Why do we fly? ecologists' sins of emission. Frontiers in Ecology and the Environment, 7(6):294-296, 2009. doi: https://doi.org/ 
10.1890/09.WB.019. URL https://esajournals.onlinelibrary.wiley.com/doi/abs/ 10.1890/09.WB.019.

D Grémillet. Paradox of flying to meetings to protect the environment. Nature Correspondence, 455:1175, 2008. doi: 10.1038/s41550-020-01216-9.

Leonor Patricia Güereca, Nathalia Torres, and Adalberto Noyola. Carbon footprint as a basis for a cleaner research institute in mexico. Journal of Cleaner Production, 47:396-403, 2013.

Seth Wynes, Simon D Donner, Steuart Tannason, and Noni Nabors. Academic air travel has a limited influence on professional success. Journal of Cleaner Production, 226:959-967, 2019.

Sam Desiere. The carbon footprint of academic conferences: Evidence from the 14th eaae congress in slovenia. EuroChoices, 15(2):56-61, 2016.

James T Stroud and Kenneth J Feeley. Responsible academia: optimizing conference locations to minimize greenhouse gas emissions. Ecography, 38(4):402-404, 2015.

Milan Klöwer, Debbie Hopkins, Myles Allen, and James Higham. An analysis of ways to decarbonize conference travel after covid-19, 2020.

Joachim Ciers, Aleksandra Mandic, Laszlo Daniel Toth, and Giel Op't Veld. Carbon footprint of academic air travel: A case study in switzerland. Sustainability, 11(1):80, 2019.

Wouter MJ Achten, Joana Almeida, and Bart Muys. Carbon footprint of science: More than flying. Ecological indicators, 34:352-355, 2013.

Didier Barret. Estimating, monitoring and minimizing the travel footprint associated with the development of the athena x-ray integral field unit. Experimental Astronomy, pages $1-34,2020$.

Ministère de l'environnement de l'énergie et de la mer MEEM. Méthode pour la réalisation des bilans d'émissions de ges, conformément à l'article 1.229-25 du code de l'environnement, 2016.

Association pour l'Avenir du Véhicule Electro-Mobile AVEM. Estce que le véhicule électrique est polluant? http://www.avem.fr/ actualite-est-ce-que-le-vae-est-polluant-5861.html, 2015.

Arcadis. Extrait de l'étude portant sur l'impact environnemental des trottinettes électriques. Étude de cas dans le contexte parisien. https://www.arcadis.com/media/4/9/7/ \%7B49782BE2-FC09-448D-8A79-EDDD02BB2D3D\%7DExtrait-Etude-Trottinettes.pdf, 2019.

World Resources Institute WRI and World Business Councilfor Sustainable Development WBCSD. The greenhouse gas protocol, a corporate accounting and reporting standard. revised edition, 2004.

\section{A Appendix tables}


Table 2: Translation of the sources of emissions used in GES 1point5 and presented in Figure 3. The three scopes correspond to those of the GHG protocol.

\section{Scope 1}

\begin{tabular}{|l|l|l|}
\hline 1 & $\begin{array}{l}\text { Émissions directes des sources fixes de } \\
\text { combustion }\end{array}$ & $\begin{array}{l}\text { Direct emissions from stationary com- } \\
\text { bustion sources }\end{array}$ \\
\hline 2 & $\begin{array}{l}\text { Émissions directes des sources mobiles } \\
\text { à moteur thermique }\end{array}$ & $\begin{array}{l}\text { Direct emissions from mobile combus- } \\
\text { tion sources }\end{array}$ \\
\hline 3 & $\begin{array}{l}\text { Emissions directes des procédés hors } \\
\text { énergie }\end{array}$ & $\begin{array}{l}\text { Direct emissions from non-energy pro- } \\
\text { cesses }\end{array}$ \\
\hline 4 & Émissions directes fugitives & Direct fugitive emissions \\
\hline 5 & $\begin{array}{l}\text { Emissons issues de la biomasse (sols et } \\
\text { forêts) }\end{array}$ & Emissions from biomass (soils, forests) \\
\hline
\end{tabular}

\section{Scope 2}

\begin{tabular}{|l|l|l|}
\hline 6 & $\begin{array}{l}\text { Émissions indirectes liées à la consom- } \\
\text { mation d'électricité }\end{array}$ & $\begin{array}{l}\text { Indirect emissions from purchased elec- } \\
\text { tricity }\end{array}$ \\
\hline 7 & $\begin{array}{l}\text { Emissions indirectes liées à la consom- } \\
\text { mation de vapeur, chaleur ou froid }\end{array}$ & $\begin{array}{l}\text { Indirect emissions from steam, heating } \\
\text { or cooling }\end{array}$ \\
\hline
\end{tabular}

\section{Scope 3}

\begin{tabular}{|l|l|l|}
\hline 8 & $\begin{array}{l}\text { Emissions liées à l'énergie non incluse } \\
\text { dans les catégories "émissions directes } \\
\text { de GES" et "émissions indirectes de } \\
\text { GES associées à l'énergie" }\end{array}$ & $\begin{array}{l}\text { Emissions linked to energy non in- } \\
\text { cluded in the "Direct emissions" and } \\
\text { "Indirect emissions associated with en- } \\
\text { ergy" categories }\end{array}$ \\
\hline 9 & Achats de produits ou services & Purchased goods and services \\
\hline 10 & Immobilisation des biens & Fixed assets \\
\hline 11 & Déchets & Waste \\
\hline 12 & Transport de marchandises amont & Transportation of goods upstream \\
\hline 13 & Déplacements professionnels & Employee business travel \\
\hline 14 & Actifs en leasing amont & Leased assets upstream \\
\hline 15 & Investissements & Investments \\
\hline 16 & Transports de visiteurs et de clients & Customer and visitor travel \\
\hline 17 & Transport de marchandise aval & Transportation of goods downstream \\
\hline 18 & Utilisation de produits vendus & Use of sold products \\
\hline 19 & Fin de vie des produits vendus & End of life of sold products \\
\hline 20 & Franchise aval & Franchises downstream \\
\hline 21 & Leasing aval & Leased assets downstream \\
\hline 22 & Déplacements domicile travail & Employee commuting \\
\hline 23 & Autres émissions indirectes & Other indirect emissions \\
\hline
\end{tabular}


Table 3: Translation of the terms used in the carbon footprint table presented in Fig. 4

\begin{tabular}{|l|l|l|}
\hline Carbon footprint & Emissions in $\mathrm{kg} \mathrm{CO}_{2} \mathrm{e}$ & Share of total fooprint \\
\hline $\begin{array}{l}\text { Carbon footprint of the } \\
\text { buildings }\end{array}$ & & \\
\hline - Heating & & \\
\hline - Electricity & & \\
\hline - Refrigerant gases & & \\
\hline Travel carbon footprint & & \\
\hline - Commutes & & \\
\hline - Vehicles & & \\
\hline - Professional travel & & \\
\hline
\end{tabular}

